University of Wollongong

Research Online

Faculty of Engineering and Information

Faculty of Engineering and Information

Sciences - Papers: Part A

Sciences

$1-1-2014$

Coupled hydro-geochemical modelling of a permeable reactive barrier for treating acidic groundwater

Buddhima Indraratna

University of Wollongong, indra@uow.edu.au

Punyama Pathirage

University of Wollongong, pp695@uowmail.edu.au

Kerry Rowe

Queens University

Laura Banasiak

University of Wollongong, Ibanasia@uow.edu.au

Follow this and additional works at: https://ro.uow.edu.au/eispapers

Part of the Engineering Commons, and the Science and Technology Studies Commons

Research Online is the open access institutional repository for the University of Wollongong. For further information contact the UOW Library: research-pubs@uow.edu.au 


\title{
Coupled hydro-geochemical modelling of a permeable reactive barrier for treating acidic groundwater
}

\author{
Abstract \\ This study focuses on coupling geochemistry with geo-hydraulics to enable time-dependent modelling of \\ the remediation of acidic groundwater using an alkaline permeable reactive barrier (PRB). Chemical \\ clogging due to secondary mineral precipitates reduces the porosity and hydraulic conductivity of the \\ reactive medium. The governing equations are incorporated into commercial numerical codes, MODFLOW \\ and RT3D. An original algorithm was developed for RT3D to simulate geochemical reactions occurring in \\ the PRB. The results and the model predictions are in agreement, confirming that the hydraulic \\ conductivity reduction due to mineral precipitation occurs at the start of permeation and continues until \\ halfway through the testing phase.

\section{Keywords} \\ geochemical, groundwater, hydro, acidic, coupled, treating, barrier, reactive, permeable, modelling

\section{Disciplines} \\ Engineering | Science and Technology Studies

\section{Publication Details} \\ Indraratna, B., Pathirage, P., Rowe, K. \& Banasiak, L. (2014). Coupled hydro-geochemical modelling of a \\ permeable reactive barrier for treating acidic groundwater. Computers and Geotechnics, 55 (January), \\ 429-439.
}




\section{Coupled hydro-geochemical modelling of a permeable reactive barrier for treating acidic groundwater}

Buddhima Indraratna $^{\mathrm{a} *}$, Punyama Udeshini Pathirage ${ }^{\mathrm{b}}$, R. Kerry Rowe ${ }^{\mathrm{c}}$ and Laura Banasiak ${ }^{\mathrm{d}}$

${ }^{a}$ Professor of Civil Engineering and Research director, Centre for Geomechanics and Railway Engineering; Program Leader, ARC Centre of Excellence for Geotechnical Science and Engineering; University of Wollongong, Wollongong City, NSW 2522, Australia; email: indra@uow.edu.au (*Corresponding author)

${ }^{b} \mathrm{PhD}$ Candidate, Centre for Geomechanics and Railway Engineering, University of Wollongong, Wollongong City, NSW 2522, Australia; email: pp695@uowmail.edu.au

'Professor and Canada Research Chair in Geotechnical and Geoenvironmental Engineering, Department of Civil Engineering; Queens University, Kingston, ON K7L 3N6 Canada; email: kerry@civil.queensu.ca

${ }^{\mathrm{d}}$ Research Fellow, Centre for Geomechanics and Railway Engineering, University of Wollongong, Wollongong City, NSW 2522, Australia; email: lbanasiak@uow.edu.au

This study focuses on coupling geochemistry with geo-hydraulics to enable time-dependent modelling of the remediation of acidic groundwater using an alkaline permeable reactive barrier (PRB). Chemical clogging due to secondary mineral precipitates reduces the porosity and hydraulic conductivity of the reactive medium. The governing equations are incorporated into commercial numerical codes, MODFLOW and RT3D. An original algorithm was developed for RT3D to simulate geochemical reactions occurring in the PRB. The results and the model predictions are in agreement, confirming that the hydraulic conductivity reduction due to mineral precipitation occurs at the start of permeation and continues until halfway through the testing phase.

Keywords: acidic groundwater, chemical clogging, permeable reactive barrier, mineral precipitation, transport modelling 


\section{Introduction}

Acidic groundwater generated from acid sulfate soil (ASS), which occupies over 200,000 $\mathrm{km}^{2}$ of the Australian land is a major environmental and socio-economic problem in Australia. Changes in land use pattern (e.g., construction of deep flood mitigation drains) and hydrological systems (e.g., rainy and drought seasons) can promote the oxidation of ASS (pyrite) in shallow zones, with the associated generation of sulfuric acid in soil, which results in mobilizing toxic metals (aluminium (Al) and iron (Fe)) from the soil [1], [2], [3]. Therefore, the transportation of acidic water along with high concentrations of dissolved $\mathrm{Al}$ and $\mathrm{Fe}$ towards the water bodies has significantly degraded the coastal environment of Australia.

A permeable reactive barrier (PRB) offers an in-situ technology for passive treatment of contaminated groundwater [4], [5], [6], [7]. Recycled concrete has been recommended as one of the suitable reactive media for the PRB based on the batch test analysis among 24 different types of alkaline materials [8] for its ability to remove Al and Fe effectively out of solution, and most importantly to maintain near neutral $\mathrm{pH}$ for a considerable time. A pilot-scale PRB $(17.7 \mathrm{~m} \times 1.2 \mathrm{~m} \times 3.0 \mathrm{~m})$ was installed in the acid sulphate soil terrain located in Lower Shoalhaven floodplains area near the town of Bombaderry, (about $100 \mathrm{~km}$ South of Sydney) in October 2006 (Fig. 1). The PRB was filled with crushed recycled concrete $\left(\mathrm{d}_{50}=40 \mathrm{~mm}\right)$ and the trench was lined with geotextile fabric to protect the reactive media from physical clogging by soil and other fine particles entering the barrier. A total of 30 observation wells and 15 piezometers were installed inside, up-gradient and down-gradient of the PRB to monitor phreatic surface variations, hydraulic gradients, permeability and groundwater chemistry. Groundwater elevation and water quality parameters such as $\mathrm{pH}$, oxidation reduction potential (ORP) and temperature were directly measured in the field every month from October 2006 using water level meter and multi-parameter field electrode probes. In 
addition, $\mathrm{pH}, \mathrm{DO}$ (dissolved oxygen), water pressure, and temperature were measured hourly by two multi-parameter automated data loggers installed within the barrier. Groundwater samples were collected frequently for analysis of iron, aluminium, major cations, anions and other trace metals. To the knowledge of the authors, this is only the second pilot scaled PRB under reducing conditions that has been installed for treating acidic water from acid sulphate soil after a natural limestone PRB reported by [9].

Generally the performance of PRBs has been satisfactory [4], [10], [11], [12], [13], [14]. On the other hand, questions remain about the long-term efficiency of PRBs that are expected to function for decades or longer [5], [15], [16]. The performance of PRBs has been hindered by mineral fouling wherein the pore space is reduced by mineral precipitation in the reactive media. Fouling of the pore spaces reduces the porosity and hydraulic conductivity of the reactive medium [16], [17], [18], [19], [20], [21], [22], [23], [24], which then directly affects the reorientation of flow paths and changes reactive times. Porosity reductions due to secondary mineral precipitation usually are calculated by the volumes of secondary minerals observed in cores or from stoichiometric calculations using measured changes in aqueous concentrations [5]. Porosity reduction model developed by [25] for an in situ reactive barrier for the treatment of hexavalent chromium and trichloroethylene in groundwater has used the transition state theory (Eq. 1) to model secondary mineral formation in treatment zone and surface area reduction method to model the depletion of reactive material of zero-valent iron (Eq. 2). Simulations based on [25], the decrease in volume fraction was approximately 0.5 to 0.42 after 20 years in the reactive barrier.

$$
\begin{aligned}
& r=-k_{e f f}\left(1-\frac{I A P}{K_{e q}}\right) \\
& S_{F e^{0}}=S_{F e^{0}}^{0}\left(\frac{\varphi_{F e^{0}}}{\varphi_{F e^{0}}^{0}}\right)^{2 / 3}
\end{aligned}
$$


Moreover, the porosity reductions of nine PRBs are reported by [26], indicating the porosity reductions range from $0.0007-0.03$ per year. $\mathrm{Li}$ [5], [26] also used Eq. 1 to develop the geochemical algorithm and Eq. 2 for reactive surface area reduction of zero-valent iron. The current study too adopted the transition state theory (Eq. 1) to develop the geochemical algorithm for the secondary minerals precipitation and for the dissolution of Ca-bearing minerals in the reactive media. Eq. 2 was not used to model the depletion of recycled concrete aggregates' surface area, as the surface area is not $100 \%$ consists of reactive material (Ca-bearing minerals) [27].

Usually the porosity reductions due to secondary mineral precipitation are greater near the entrance face and diminish with distance into the PRB. Wilkin [14] reported the zero-valent iron medium at US Coast Guard Support Centre had a decrease in porosity by 0.032 within the first $25 \mathrm{~mm}$ from the entrance face after eight years of operation. Liang [28] used saturation indices of each and every mineral in the system to predict which ones precipitate and which ones dissolve. Liang's [28] model for porosity reduction due to secondary mineral precipitation simulated over 10 years gave $0.188,0.672,1.150$ and 0.918 reductions in PRBs located at Portsmouth, Moffett field, Monticello and Y-12 site respectively. Although the porosity reduction at entrance face was significant, about $80 \mathrm{~mm}$ in to the iron medium, the porosity reduction diminished to less than 0.00002 . Further studies done by [5], considering the effect of different parameters (geochemical parameters, influent concentration, rate coefficients and aquifer parameters) for porosity reduction in PRBs show that maximum porosity reduction was attained at the entrance face and diminishes with distance going into the PRB. 

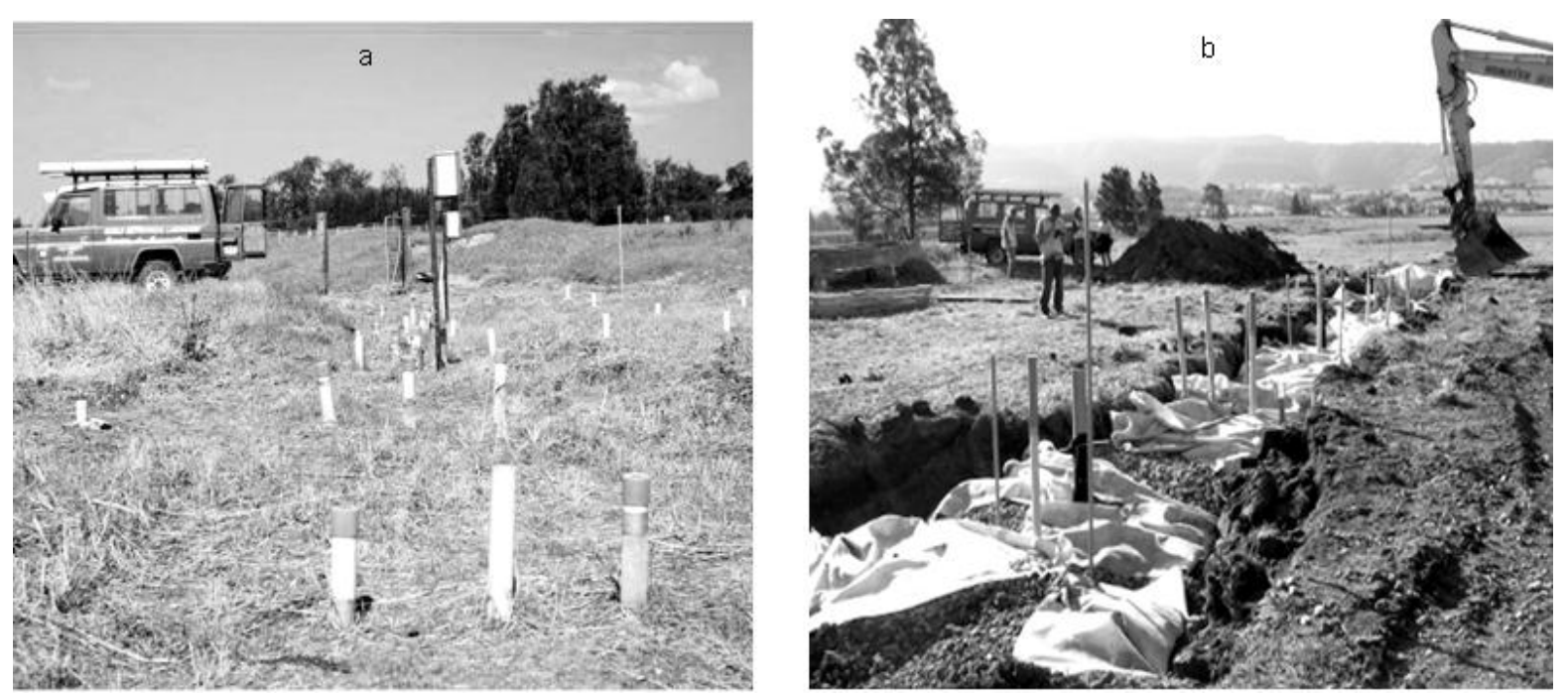

Figure 1: (a) Pilot-scale PRB with piezometers and monitoring wells in ASS terrain on Shoalhaven Floodplain, southeast NSW and (b) installation of the PRB

The intent of this study was to develop a model to understand mineral fouling in PRBs in ASS terrains, incorporating a calibrated flow and a reactive transport model to simulate mineral deposition and its effects on hydraulic parameters. To achieve that, a comprehensive geochemical algorithm describing the most dominant reactions was developed and coupled to a transient groundwater flow model. An analytical solution was developed to capture the change in hydraulic head with associated changes in porosity and hydraulic conductivity. This head will be the input into MODFLOW which in return will be used to couple the groundwater flow with reaction kinetics in RT3D. User-defined module facilitated in RT3D was used to feed the geochemical algorithm into the numerical codes. This model is beneficial for practising engineers and scientists who have to deal with ASS especially in coastal areas of Australia.

\section{Methodology}

\subsection{Laboratory column experiments}




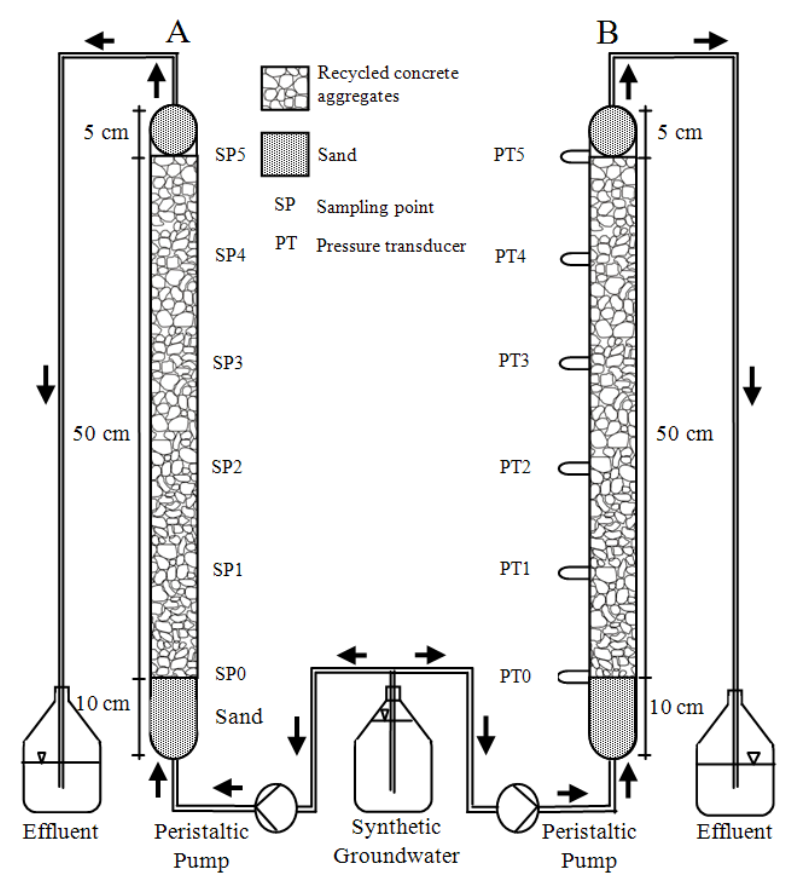

Figure 2: $\quad$ Schematic diagram of the laboratory column experiments: A is the sampling column and B is the pressure measuring column

Laboratory column experiments were carried out under constant flow of $1.2 \mathrm{~mL} / \mathrm{min}$

(millilitres per minute) using a Masterflex peristaltic pump (Fig. 2). Two simultaneous

column experiments were run as suggested by [29] one for sampling and one to take pressure readings. The purpose of running two simultaneous columns instead of one column was to eliminate the impact of sampling activities on the pressure in the column [29]. The pressures at the onset were measured for both columns using pressure transducers at both ends which were almost the same. The input and environmental conditions were maintained the same for both columns, so the pressure readings calculated at each port was assumed similar to the respective sampling port at the same height in the other column.

The crushed recycled concrete used in this study was a waste material discarded after the demolition of old concrete structures. The particle size of crushed concrete was chosen such that it passed the $4.75 \mathrm{~mm}$ sieve and was retained on the $3.35 \mathrm{~mm}$ sieve to ensure a uniform particle size. Quantitative X-ray diffraction (QXRD) analysis indicated that the major cations (by 
weight) in the solid recycled concrete were: $\mathrm{Ca}(57.3 \%), \mathrm{Fe}(21.4 \%), \mathrm{Al}(9.85 \%), \mathrm{Mg},(5.27 \%), \mathrm{Si}$ (3.06\%) and others (3.04\%) [24], [27]. The main Ca-bearing minerals incorporated in the model are $\mathrm{CaAl}_{2} \mathrm{Si}_{2} \mathrm{O}_{8}(16.8 \%$ by weight $), \mathrm{CaCO}_{3}(4.4 \%$ by weight $)$ and $\mathrm{Ca}(\mathrm{OH})_{2}(0.3 \%$ by weight $)$ as given in [27].

The experiments were conducted in transparent acrylic columns (Fig. 2; Internal diameter $x$ Length $=5 \mathrm{~cm} \times 65 \mathrm{~cm}$ ) with $10 \mathrm{~cm}$ of silica sand at the bottom followed by $50 \mathrm{~cm}$ of crushed recycled concrete, and topped with another $5 \mathrm{~cm}$ of silica sand. Pure silica sand (chemically inert) placed at the top and bottom of the columns provided effective filtration for the simulated groundwater. The influent and effluent ports were separated from the silica sand using a geotextile separator to prevent physical clogging by the sand. The water flow was directed from bottom to top to maintain saturated conditions. The input solution for the column was a synthetic acidic water (Table 1) prepared as to be comparable to the average groundwater from ASS terrain in southeast of NSW, Australia as presented by [3] and [24]. Table 1: Water Chemistry of the influent solution prepared for column experiment simulating the water chemistry of the acidic groundwater in ASS terrain presented in [22]

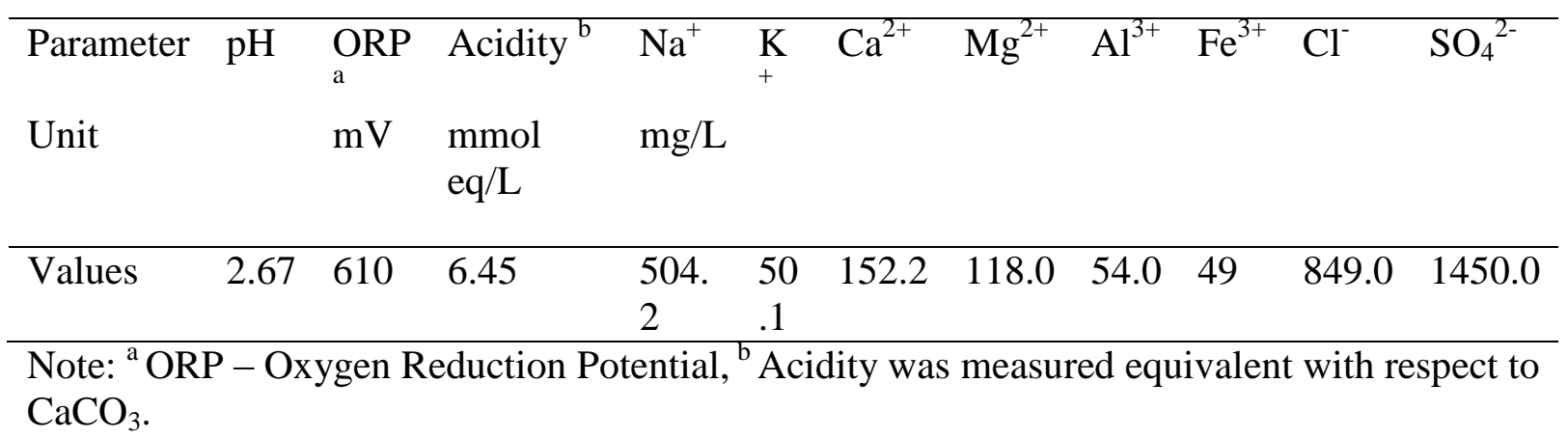

The samples were collected every $10 \mathrm{~cm}$ along the column. The effluents collected from sampling points and at the end of the column experiment were analysed for $\mathrm{Ca}, \mathrm{Al}$ and $\mathrm{Fe}$ concentration. $\mathrm{Ca}$ and $\mathrm{Al}$ were analysed using ICP-MS (Inductively Coupled Plasma - Mass Spectrometry) and Fe was analysed using AAS (Atomic Absorption Spectroscopy). All 
chemical analyses were performed following the standard method for water and wastewater [30].

\subsection{Geochemical algorithm}

A systematic geochemical algorithm was developed using the transition state theory used by [23], [26], [27], [31] and [32]. This is the first geochemical algorithm developed for treating acidic groundwater using recycled concrete filled PRB. There are thirteen primary mineral dissolution-precipitation reactions as shown in [3]. To confirm the adoption of only these thirteen reaction equations in the geochemical algorithm, inverse geochemical modelling has been carried out by [22] which consider all the possible mineral phases in the upstream of the PRB and inside the PRB. The results from inverse geochemical modelling confirmed that these thirteen reactions are the dominant reactions in terms of acid neutralisation. Moreover, the other minerals in the influent water as listed in Table 1 , do not contribute to the acid neutralisation procedure. Fig. 3 shows that the effluent concentrations of these ions do not change significantly during the column experiments.

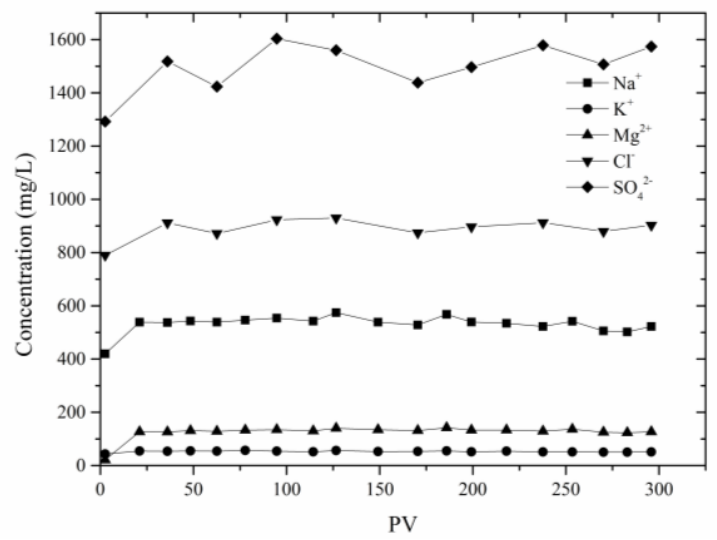

Figure 3: Other ions in the effluent which do not change significantly with time The geochemical reactions were assumed to occur in parallel and the relevant equations were solved simultaneously. The concentration of each species was calculated for each cell in the finite difference grid during each time step. 
The kinetics of mineral dissolution and precipitation were assumed to follow the transition state theory (Eq. (1)) as reported by many researchers worked on PRB studies [26], [31], [33], [34].

Li [5] used extended Debye-Huckle equation for the activity correction and data provided in [35] for the solubility constants. In this study, saturation indices (SI) which can be calculated from PRHEEQC software was used to get the value for $I A P / K_{e q}$ as given in Eq. (3) [27], [36].

$S I=\log (I A P)-\log \left(K_{e q}\right)$

Saturation indices for minerals dissolving $(S I<0)$ and precipitating $(S I>0)$ were calculated from PHREEQC software based on the concentration in the influent water $\left(\mathrm{Na}^{+}, \mathrm{K}^{+}, \mathrm{Ca}^{2+}\right.$, $\mathrm{Mg}^{2+}, \mathrm{Al}^{3+}, \mathrm{Fe}^{3+}, \mathrm{Cl}^{-}, \mathrm{SO}_{4}{ }^{2-}$, alkalinity, $\mathrm{pH}$ and temperature). The mineral reactions and geochemical algorithm are given in the Appendix A. The effective rate coefficient $\left(k_{e f f}\right)$ was assumed to be time invariant and spatially homogeneous throughout the simulation [5].

\subsection{Change of mineral quantity over time}

Secondary mineral precipitates produced in the recycled concrete media were assumed to be immobile. The pore space occupied by each mineral was calculated from the relevant molar volume. The volume reduction at a given location due to secondary mineral precipitation was computed as the total volume occupied by the mineral precipitates minus the volume achieved by the dissolution of Ca-bearing minerals in recycled concrete. The associated porosity reductions (Eq. (5)) were calculated using Eq. (4) as suggested by [33], thus $\frac{\partial \Phi_{k}}{\partial t}=M_{k} R_{k}$ 
Hence the change in porosity with time can be obtained from;

$$
n_{t}=n_{0}-\sum_{k=1}^{N_{m}} M_{k} R_{k} t
$$

The product of $M_{k} R_{k}$ is constant for a given time step. In the next time step, the new value of $R_{k}$ is introduced to the equation based on the results obtained from Eqs. 1 and 3 for respective time steps.

The normalised Kozeny Carmen equation (Eq. (6)) was used to estimate the hydraulic conductivity at different pore volumes (PV) with the change of dissolved/precipitated minerals with time [5], [24].

$$
K=K_{0}\left[\frac{n_{0}-\Delta n_{t}}{n_{0}}\right]^{3} /\left[\frac{1-n_{0}+\Delta n_{t}}{1-n_{0}}\right]^{2}
$$

\subsection{Groundwater flow model and reactive transport flow model}

The software codes MODFLOW and RT3D were used to simulate the transport and fate of the major cations in the column. MODFLOW simulates the groundwater flow using blockcentred finite difference approach [37]. The column experiment was considered to be a confined aquifer with transient flow conditions. The crushed concrete in the column was assumed to be homogeneous and isotropic. Authors have selected a relatively uniform particle gradation for the column test and have also assumed that the particle angularity is generally similar (as it was impossible to find all rounded particles of broken concrete aggregates). Therefore, for the simplicity the assumption of a continuum with homogeneity and isotropy is made along the column length. Since the flow is only vertical (1D) in the column, the negative implications of this assumptions are expected to be minimal. Indraratna [38] has indicated that for granular media, the width or diameter of the test chamber to maximum particle size ratio $>8$ would make boundary effects generally insignificant. The same concepts have been applied for filtration testing of rail ballast and other rockfill for 
dams [39]. In this study, given the diameter of the column as $50 \mathrm{~mm}$, and the maximum particle size approximately $4-5 \mathrm{~mm}$, the corresponding ratio is above 10 , hence, boundary effects can be considered to be insignificant.

Table 2 summarises the experimental parameters and model inputs. The side of the column were no-flow boundaries.

Table 2: $\quad$ Experimental and model parameters

\begin{tabular}{llll}
\hline Property & Experiment & Model (Lab) & Model (Field) \\
\hline Flow & $1.2 \mathrm{~mL} / \mathrm{min}$ & $1.2 \mathrm{~mL} / \mathrm{min}$ & $1.1 \times 10^{6}$ L/year \\
Initial porosity $\left(\mathrm{n}_{0}\right)$ & 0.69 & 0.69 & 0.5 \\
Initial hydraulic & $0.9565 \mathrm{~m} / \mathrm{d}$ & $0.9565 \mathrm{~m} / \mathrm{d}$ & $0.1 \mathrm{~m} / \mathrm{s}$ \\
$\begin{array}{l}\text { conductivity }\left(\mathrm{K}_{0}\right) \\
\text { pH of influent }\end{array}$ & 2.8 & 2.8 & 3.6 \\
\hline
\end{tabular}

Transient groundwater flow in one dimension is governed by:

$\frac{\partial^{2} h}{\partial x^{2}}=\nabla^{2} h=\frac{S}{T}\left(\frac{\partial h}{\partial t}\right)$

$T=K b$

The variation in hydraulic conductivity due to dissolution/precipitation of minerals can be calculated from Eq. (6). The solution for Eq. (7) considering the changes in hydraulic conductivity (Eq. (6)) can be written as,

$h=\left(\exp \left[-\frac{\mu^{2} b K_{0}}{S \sum_{k=1}^{N_{m}} M_{k} R_{k}} \frac{\left(1-n_{0}\right)^{2}}{n_{0}^{3}}\left\{\alpha^{2}(1.5+1 / \beta)-3(\alpha+\ln \beta)\right\}\right] \cdot(C \sin \mu x+D \cos \mu x)\right.$

where, $\alpha=n_{0}+\sum_{k=1}^{N_{m}} M_{k} R_{k} t$

$\beta=1-n_{0}-\sum_{k=1}^{N_{m}} M_{k} R_{k} t$

The step by step procedure for obtaining Eq. (9) is illustrated in Appendix B. 
The following initial conditions can be used to calculate the values for $\mu, C$ and $D$.

$h=h_{1}$ at $x=0$ and $t=0$,

$h=h_{2}$ at $x=l$ and $t=0$,

$\frac{\partial h}{\partial t}=0$ at $x=0$ and $t=0$

Eq. (9) was used to calculate the starting head for MODFLOW at every time step. The reason to adopt this approach was because MODFLOW does not have a way of automatically changing the porosity or the hydraulic conductivity unless they are manually entered. It was important to update these values at every time step due to the changes in volume fractions of primary and secondary minerals. For instance, when the model is run for the $1^{\text {st }}$ time step, the corresponding values of porosity and hydraulic conductivity are updated for the $2^{\text {nd }}$ time step, and Eq. 9 is now required to determine the resulting head as that is an essential input for MODFLOW to continue the analysis for subsequent time steps. MODFLOW was used to couple the chemical reaction component developed in RT3D with advection, diffusion and dispersion (Eq. 13) using finite difference method. Once the starting head was calculated by the analytical model, the results were put into MODFLOW. Then MODFLOW and RT3D were run in tandem to get the concentrations of reactants at every time step.

RT3D is a three-dimension multi-component transport model which has the ability to solve coupled partial differential equations describing advective-dispersive-reactive transport of aqueous and solid phase species in saturated groundwater flow systems [40]. The program consists of seven pre-defined reaction modules, and a "user-defined" reaction module. The user-defined module was used in this study to simulate the geochemical reactions occur in PRBs for acidic groundwater remediation using recycled concrete. The governing equation for fate and transport of aqueous species [5], [40], [41] is: 
$R \frac{\partial C}{\partial t}=D \frac{\partial^{2}[C]}{\partial x^{2}}-v \frac{\partial[C]}{\partial x}-\lambda C$

For the dissolution/precipitation reactions, $r$, the kinetic reaction expression in Eq. (1)

multiplied by $M$ (molar volume of the substance) can be substituted for $\lambda$.

RT3D can solve the fate and transport equation for aqueous species along with the governing equation for solid phase species [41]:

$\frac{\partial \tilde{C}}{\partial t}=\tilde{r}$

RT3D uses a split-operator numerical strategy to solve the aqueous and solid phase equations, which are coupled through the reaction rate terms via stoichiometry. RT3D solves advection and dispersion sequentially for all aqueous species in a transport time step. Then the coupled reaction terms for aqueous and solid species are solved in the same time step. In this study, the advection component, dispersion component and reaction equations were solved with the implicit finite-difference method. Because of their potential variability of in-situ rate coefficients [5], the kinetic reaction rate coefficient $\left(k_{\text {eff }}\right)$ was obtained for $\mathrm{Ca}^{2+}, \mathrm{Al}^{3+}$ and Total $\mathrm{Fe}\left(\mathrm{Fe}^{2+}\right.$ and $\left.\mathrm{Fe}^{3+}\right)$ (Table 3$)$ by calibrating the model against the laboratory column data provided by [27] and using the molar weights of $\mathrm{Ca}^{2+}, \mathrm{Al}^{3+}, \mathrm{Fe}^{2+}$ and $\mathrm{Fe}^{3+}$. The calibrated rate coefficients were obtained by manual trial and error as undertaken by [5]. The corresponding reaction kinetics (listed in Table 3) were then used to validate the current model using the column experiment data of this study. The calibration was done for 40-190 PV range using [27] data and the Authors' model was validated for the same PV range. This is an important experimental phase for maintaining neutral $\mathrm{pH}$ and for $100 \%$ removal of $\mathrm{Al}$ and Fe ions. Model parameters used for calibration and validation process are listed in Table 4. 
Table 3: $\quad$ Kinetic reaction rate coefficients $\left(k_{\text {eff }}\right)$ for the mineral dissolution/precipitation which are calibrated values from the data provided by [27].

\begin{tabular}{|c|c|c|}
\hline Mineral phase & $\begin{array}{lcr}\text { Kinetic } \quad \text { reaction } & \text { rate } \\
\text { coefficient }\left(k_{\text {eff }}\right)(\mathrm{mol} / \mathrm{L.s}) & \end{array}$ & $\begin{array}{l}\text { Kinetic reaction rate } \\
\text { coefficient }\left(k_{e f f}\right)(\mathrm{mol} / \mathrm{L} . \mathrm{s}) \\
\text { in literature }^{\mathrm{e}}\end{array}$ \\
\hline $\mathrm{Ca}^{2+}$ & $2.27 \times 10^{-7}$ & $\left(1 \times 10^{-6}\right)$ \\
\hline $\mathrm{Al}^{3+}$ & $6.86 \times 10^{-8}$ & $\left(9.0 \times 10^{-7}-1.0 \times 10^{-8}\right)$ \\
\hline Total $\mathrm{Fe}\left(\mathrm{Fe}^{2+}\right.$ and $\left.\mathrm{Fe}^{3+}\right)$ & $5.87 \times 10^{-8}$ & $\left(1.0 \times 10^{-7}-1.2 \times 10^{-8}\right)$ \\
\hline
\end{tabular}

Note: ${ }^{\mathrm{e}}$ Source: [42] and [43]

Table 4: $\quad$ Calibration and validation parameters used in the model application for range 40-190 PV.

Calibration $\quad$ Validation

Data set

$k_{\text {eff }}$ for $\mathrm{Ca}^{2+}, \mathrm{Al}^{3+}$ and $\quad$ Data from [27] Current data

Total $\mathrm{Fe}\left(\mathrm{Fe}^{2+}\right.$ and $\left.\mathrm{Fe}^{3+}\right)$

State variables

$\left[\mathrm{Ca}^{2+}\right],\left[\mathrm{Al}^{3+}\right],\left[\mathrm{Fe}^{2+}\right]$ and Effluent concentrations (after Current data on effluent $\left[\mathrm{Fe}^{3+}\right]$ [27]) concentration

\subsection{Model application to the field PRB}

A reactive transport analysis was conducted along the centreline of the PRB. A discretisation interval of $0.1 \mathrm{~m}$ in the horizontal direction was adopted for a total width of $1.2 \mathrm{~m}$. All the equations used in the model application to the column experiment which was a vertical flow, was assumed equivalent to the horizontal flow along the centre line of the field PRB. The geochemical algorithm is independent from the effect of gravity. On the basis of field data observed during the period from October 2006 to January 2012, the flow domain was simulated as a fully saturated system with specified head boundaries and a mean hydraulic gradient of 0.006 to represent realistic field conditions. The reaction rates for simulating the PRB conditions were the same as those corresponding to laboratory column experiments albeit different boundary conditions. Also, the primary and secondary mineral components considered in the field were the same as those in the column experiments. 


\section{Results and Discussion}

The reaction between the acidic water and the concrete that caused leaching of the $\mathrm{Ca}$ also reduced the $\mathrm{pH}$ of the effluent from $\mathrm{pH} 9.6$ initially to 8 within 15 pore volumes (Fig. 4), after which there was a slow decrease (pH dropping from 7.9 at $25 \mathrm{PV}$ to 7.5 at $125 \mathrm{PV}$ ), a faster drop from $\mathrm{pH} 7.5$ at $125 \mathrm{PV}$ to about 6.8 at about $185 \mathrm{PV}$, a rapid drop from $\mathrm{pH} 6.8$ at $185 \mathrm{PV}$ to 4 at about $215 \mathrm{PV}$, and then another period with a slower rate of increase from $\mathrm{pH}$ 4 at $215 \mathrm{PV}$ to 3.1 to about $295 \mathrm{PV}$ at test termination. According to [16], the initial drop in $\mathrm{pH}$ (after $15 \mathrm{PV}$ passed through the column) was assumed to be due to the depletion of carbonate alkalinity. The model predicted values for first $\mathrm{pH}$ plateau is shown in Fig. 4. In this model prediction, $\mathrm{OH}^{-}$in the aqueous phase was assumed to be in equilibrium. However, after reaching a value of 6.8 (after $190 \mathrm{PVs}$ ), the pH subsequently diminishes to 4 (Fig. 4). This is probably due to the $\mathrm{OH}^{-}$being in equilibrium during the depletion of carbonate minerals [16]. The experimental and predicted values of $\mathrm{pH}$ along the column are shown in Fig. 5. In SP1, the rapid jump occurred at pH 6.5 in Fig. 4 is attained within 25 PVs, which is fast due to the rapid neutralisation of acidity and the exhaustion of the reactive material at the entrance of the column. In contrast in SP1, 2, 3 and 4, excessive sampling of the column was avoided in order to ensure minimum disturbance to the flow. That is probably the reason why a rapid jump was not visible in the $\mathrm{pH}$ values inside the column. In the early stages of the experiment, most of the $\mathrm{Al}$ in the synthetic groundwater precipitated shortly after entering the column and was no longer in the pore water (Fig.6). Al precipitates when the $\mathrm{pH}$ is above 4.5. $\mathrm{Al}$ was observed in the effluent water for the first time when the $\mathrm{pH}$ of the effluent dropped to 4, after which the concentration of $\mathrm{Al}$ continued to increase (Fig. 6) because of its high solubility at $\mathrm{pH}<4$. Similarly, Fe also precipitated when the $\mathrm{pH}$ exceeded 3.5. Until $255 \mathrm{PV}$, the effluent $\mathrm{pH}$ did not drop below $\mathrm{pH} 3.5$; accordingly, the Fe content of the effluent $(<1$ $\mathrm{mg} / \mathrm{L}$ ) was negligible throughout the duration of the column test (Fig. 7). 


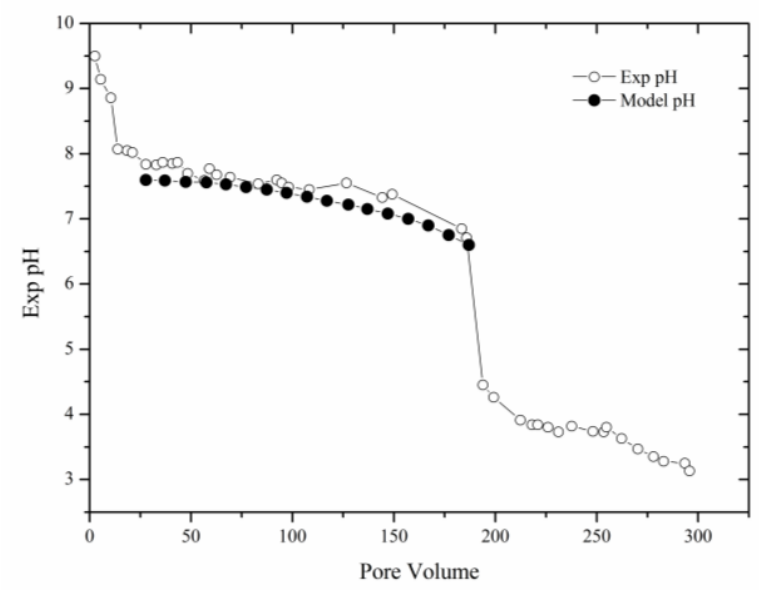

Figure 4: $\quad$ Predicted and experimental results of $\mathrm{pH}$ at the effluent

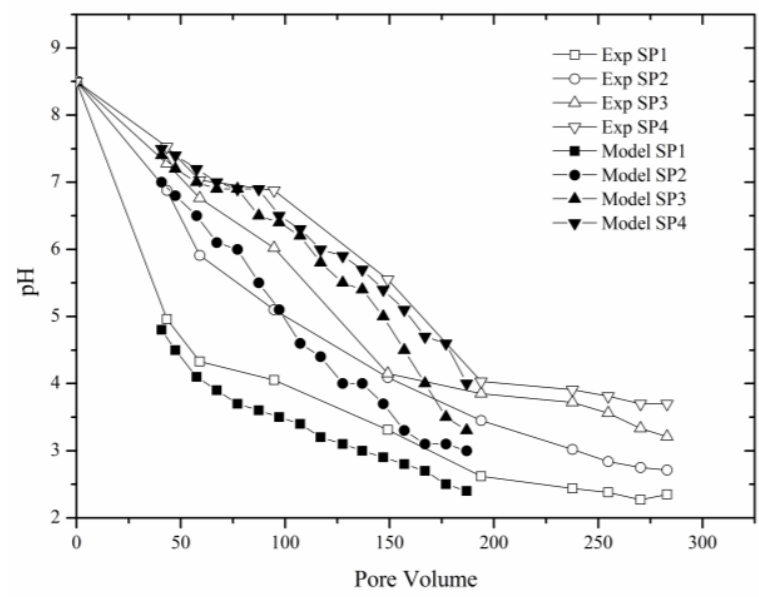

Figure 5: $\quad$ Predicted and experimental results of $\mathrm{pH}$ at the sampling points along the column

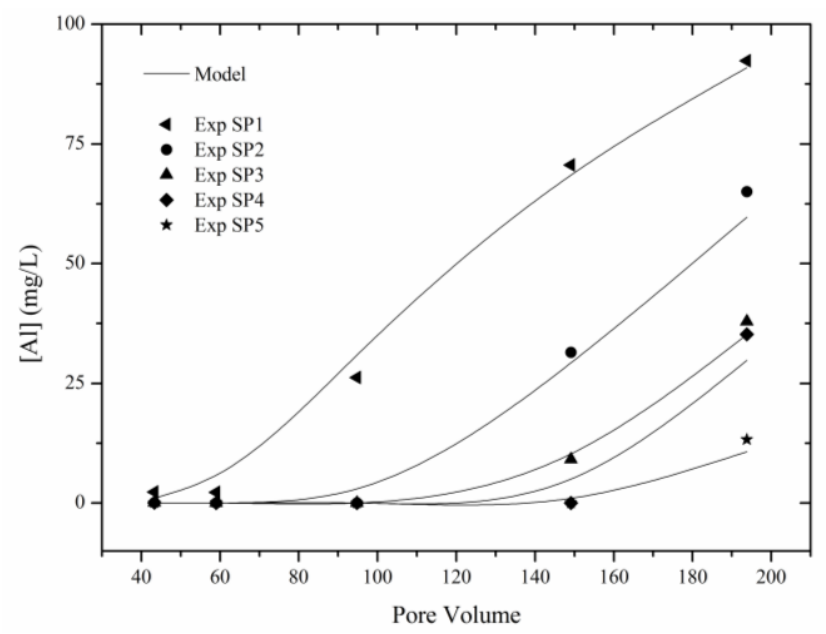


Figure 6: Calculated and measured $\mathrm{Al}^{3+}$ concentrations at sampling points along the column

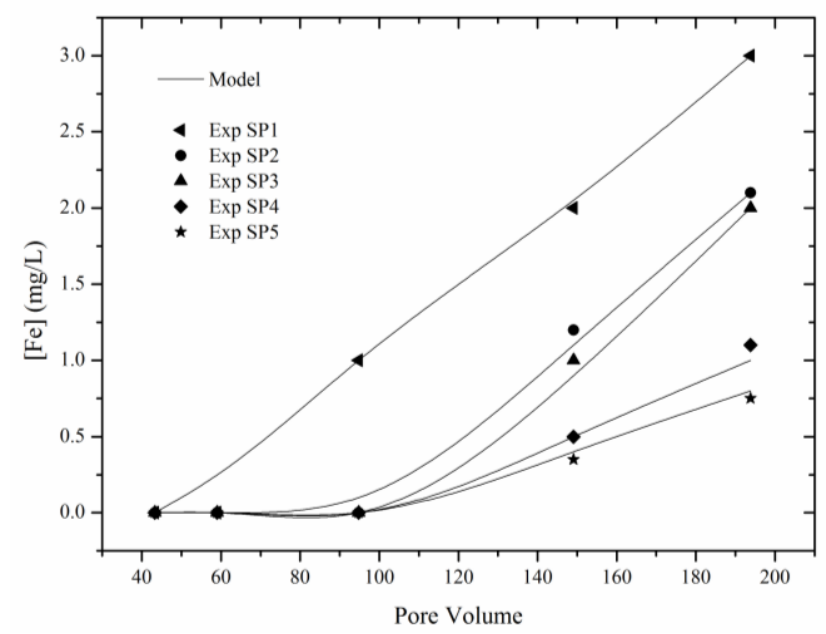

Figure 7: $\quad$ Calculated and measured total $\mathrm{Fe}\left(\mathrm{Fe}^{2+}\right.$ and $\left.\mathrm{Fe}^{3+}\right)$ concentrations at sampling points along the column

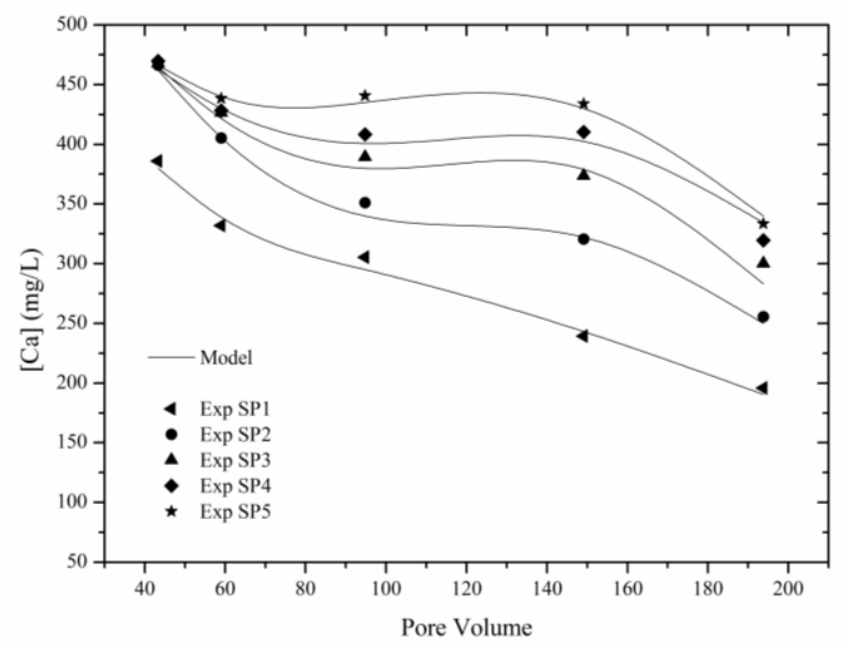

Figure 8: $\quad \mathrm{Ca}^{2+}$ concentrations of model predicted values vs. experimental values at sampling points along the column

The predicted and measured concentration profiles of $\mathrm{Al}^{3+}$, total $\mathrm{Fe}$ and $\mathrm{Ca}^{2+}$ (Figs. 6, 7 and 8) are in very good agreement. In the model, $\mathrm{Fe}^{2+}$ and $\mathrm{Fe}^{3+}$ are considered separately and later combined to compare with the experiment values. The precipitation of secondary minerals (i.e. $\left.\mathrm{Fe}(\mathrm{OH})_{3}, \mathrm{Fe}(\mathrm{OOH}), \mathrm{Fe}_{2} \mathrm{O}_{3}, \mathrm{Fe}(\mathrm{OH})_{2}, \mathrm{FeCO}_{3}, \mathrm{Al}(\mathrm{OH})_{3}\right)$ significantly decreases the efficiency of the reactive material due to the armouring effect (armouring is the coating of 
reactive surfaces of recycled concrete by precipitating minerals). The efficiency of recycled concrete would already have decreased to some extent by the exhaustion of the alkalinity of the materials. The model results obtained for porosity show that the precipitated secondary minerals subsequently reduce the porosity and hydraulic conductivity. Direct measurement of porosity using the porosity meter [44] did not provide reliable readings due to the internal disturbance of the specimen surrounding the probe tip. Therefore, some porosity values were back calculated from the Kozeny Carmen equation (Eq. 6) using the hydraulic conductivity data from experiment at different pore volumes (Table 5). The results are very similar to the predicted porosity values from Eq. 5, further confirming the accuracy of the developed model.

Table 5: $\quad$ Comparison of porosities based on Kozeny Carmen relationship with the model predictions (Eq. 5).

\begin{tabular}{cccc}
\hline PV & $\begin{array}{c}\text { Experimental } k(\mathrm{~m} / \mathrm{d}) \text { based } \\
\text { on Darcy's Law }\end{array}$ & $\begin{array}{c}n \text { back-calculated from } \\
\text { Kozeny-Carmen equation } \\
\text { (Eq. 6) }\end{array}$ & $\begin{array}{c}n \text { predicted from } \\
\text { geochemical model } \\
\text { (Eq. 5) }\end{array}$ \\
\hline 43 & 0.957 & 0.690 & 0.690 \\
59 & 0.919 & 0.685 & 0.687 \\
95 & 0.808 & 0.673 & 0.679 \\
149 & 0.682 & 0.656 & 0.668 \\
194 & 0.628 & 0.648 & 0.663 \\
\hline
\end{tabular}

Several studies carried out for zero-valent iron columns [26], [45], organic sediment columns [46], glass bead columns [19] and recycled concrete columns [27] have reported that excessive clogging is greatest near the inlet to the column (reactive materials) and is not uniform throughout the column. For the current case, the porosity and hydraulic conductivity reductions due to mineral precipitation and dissolution were calculated from Eq. (5) and (6) for each $100 \mathrm{~mm}$ interval along the column (Fig. 9 and 10). The porosity and hydraulic conductivity reductions were a maximum near where the water entered the column (Zone 1) and decreased with distance along the column (i.e., clogging in Zone $1>$ Zone $2>$ Zone 3 
etc.). This situation arises because of the reduction in dissolved ions in the solution available to precipitate as the water moves through the column. The pores in the column were large enough that complete occlusion of the pores did not occur and hence the flow could be maintained (with an increase in pressure) throughout the experiment. A similar trend in hydraulic properties was observed by [5] for the pilot-scale PRB (containing granular iron) conducted at Moffett Federal Airfield and U.S. Coast Guard Support Centre.

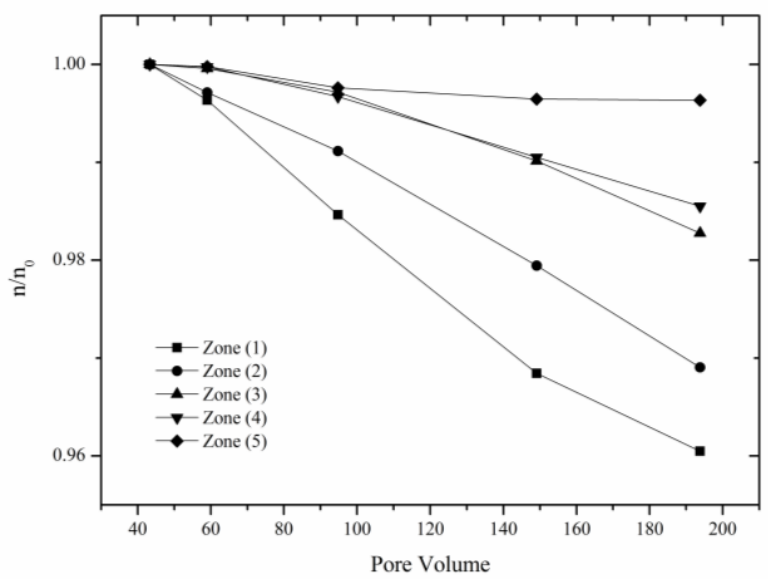

Figure 9: Normalised porosity values in Zone (1): SP1-SP2, Zone (2): SP2-SP3, Zone (3): SP3-SP4, Zone (4): SP4-SP5, Zone (5): SP5-SP6

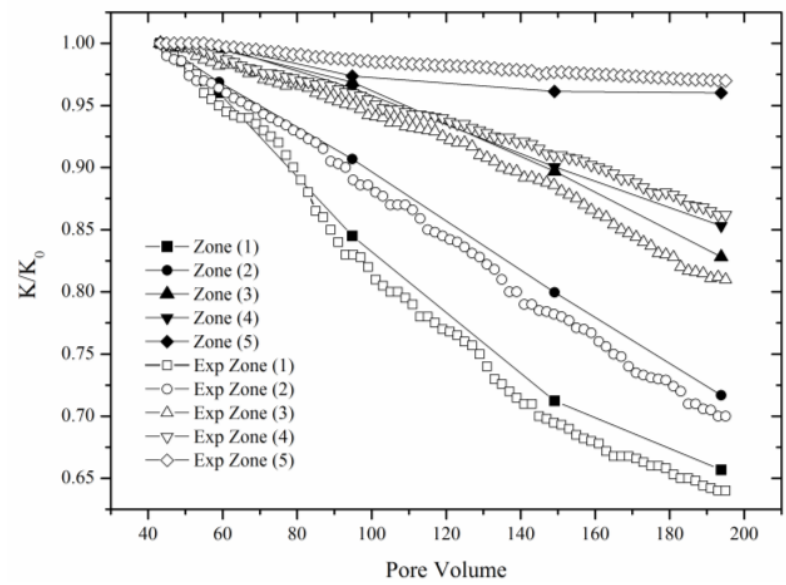

Figure 10: Experimental and predicted (normalised) hydraulic conductivity values in Zone (1): SP0-SP1, Zone (2): SP1-SP2, Zone (3): SP2-SP3, Zone (4): SP3-SP4, Zone (5): SP4-SP5 
In the application of the model to field PRB, favourable comparisons were obtained between the predictions and field measurements for $\mathrm{pH}, \mathrm{Al}$ and total Fe concentrations. Figs. 11, 12 and 13 show the model predictions and field results for $\mathrm{pH}, \mathrm{Al}$ and total $\mathrm{Fe}$ concentrations for 2012 after 6 years of operation. $\mathrm{pH}$ of groundwater up-gradient of the PRB varied between 3.2 and 4.1 with an average of 3.6, whereas inside the PRB, $\mathrm{pH}$ was higher and varied from 6.7 to 7.4 with an average of 7 . Table 6 summarises the model inputs and averaged values of field data and model outputs. The predicted $\mathrm{pH}$ values are in agreement with the sharp increase in $\mathrm{pH}$ observed at the near-neutral plateau inside the PRB. Field monitoring and column experiments indicate that the concentrations of $\mathrm{Al}^{3+}$ and total $\mathrm{Fe}$ reduce rapidly within the PRB to very low levels, in accordance with the model output. The rapid decrease in these cations indicates that secondary minerals precipitate inside the PRB resulting in a decrease of porosity and hydraulic conductivity. However, the computed decrease in hydraulic conductivity from October 2006 to October 2012 is only 3\%, which is not surprising given the larger sized recycled concrete aggregates $\left(\mathrm{d}_{50}=40 \mathrm{~mm}\right)$ used in the PRB that prolong total clogging within relatively large pores of a coarse aggregate assembly. The physical clogging due to fine particles intrusion is not captured in this geochemical model. To apply the model to a prototype PRB in the field and to predict its longevity accurately, physical clogging from suspended clay particles should also be combined with chemical clogging, which is currently being studied.

Table 6: $\quad$ Model predicted and measured $\mathrm{pH}, \mathrm{Al}$ and total Fe concentrations in the field PRB

\begin{tabular}{lccc}
\hline Input values & $\begin{array}{c}\text { Averaged measured } \\
\text { values inside the } \\
\text { field PRB }\end{array}$ & $\begin{array}{c}\text { Averaged model } \\
\text { predicted values } \\
\text { inside the field PRB }\end{array}$ \\
\hline $\mathrm{pH}$ & 3.6 & 7 & 7.3 \\
{$[\mathrm{Al}](\mathrm{mg} / \mathrm{L})$} & 27 & 1 & 0.5 \\
{$[$ Total Fe] $(\mathrm{mg} / \mathrm{L})$} & 80 & 1 & 0 \\
\hline
\end{tabular}




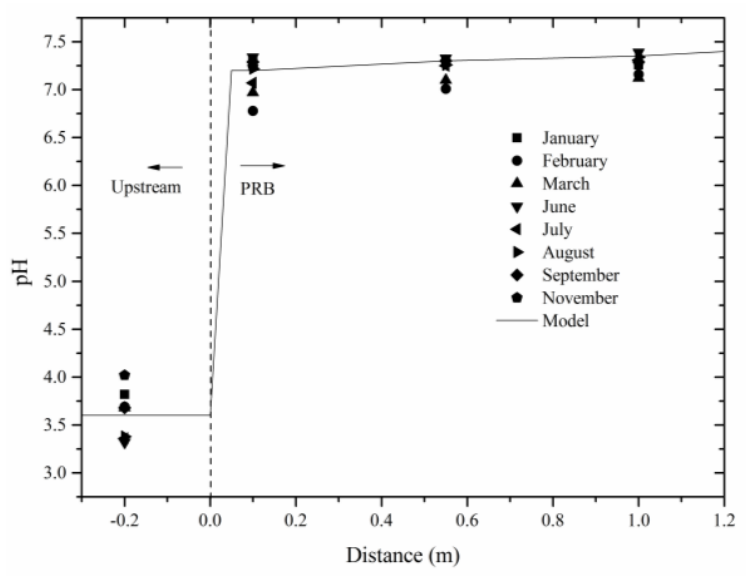

Figure 11: Measured and predicted pH values for field PRB for 2012

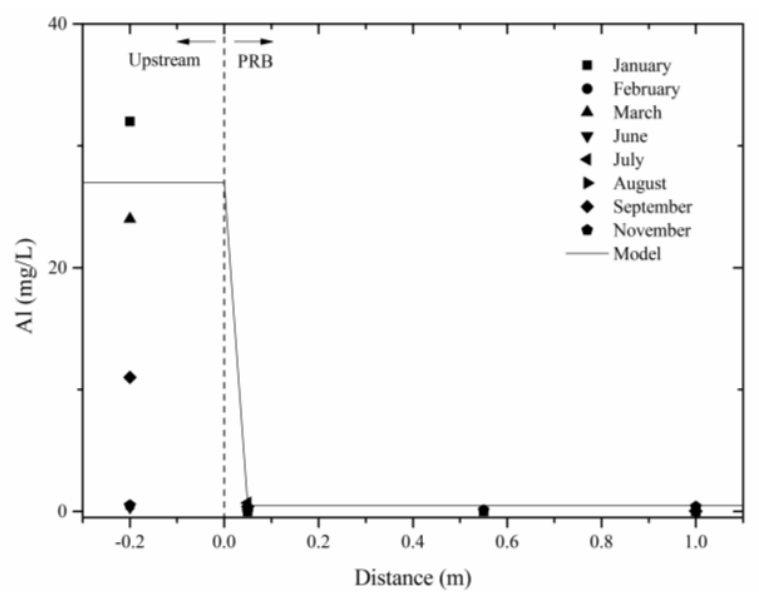

Figure 12: Measured and predicted Al concentrations for field PRB for 2012

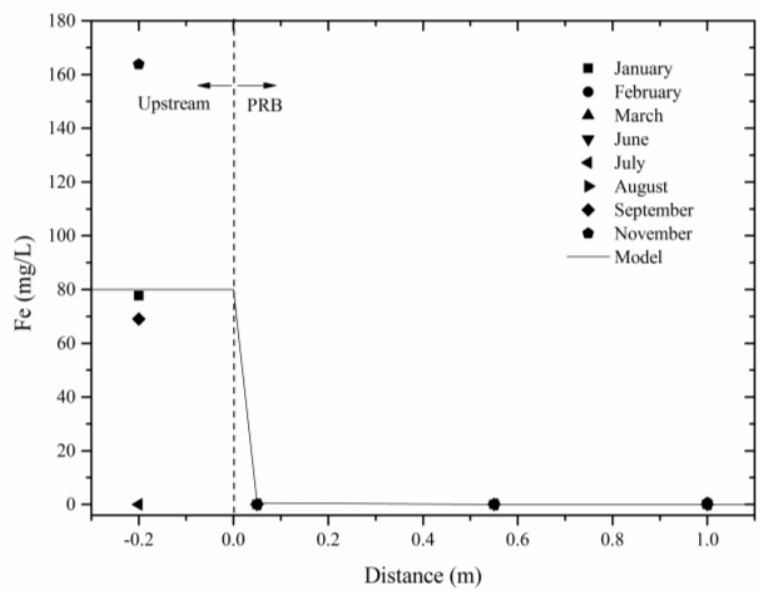

Figure 13: Measured and predicted Fe concentrations for field PRB for 2012

\section{Conclusion}


The dissolution potential of Ca-bearing minerals in recycled concrete and precipitation potential of secondary minerals out of acidic groundwater has been examined with particular attention to their impact on the hydraulic properties of crushed recycled concrete in a test column and a pilot scale PRB. MODFLOW and RT3D were used to simulate flow and the reactive transport of mineral components. A geochemical algorithm was developed for the input of RT3D specifically for simulating the geochemical reaction that occur in PRBs composed of recycled concrete for the treatment of acidic groundwater. The calculated concentrations of $\mathrm{Ca}^{2+}, \mathrm{Al}^{3+}$ and total $\mathrm{Fe}$ were in good agreement with the observed experimental and field values. Based on the results reported herein, the following conclusions were reached.

Clogging, and hence the reduction in porosity and hydraulic conductivity, was most significant where the groundwater entered the column and decreased with distance along the column. The largest porosity reduction during the experiment was most significant (4\%) near the influent end of the column and this reduced to $3 \%$ midway along the column and $0.5 \%$ near the end of the column. The porosity reduction arose from the precipitation of secondary minerals (i.e. $\left.\mathrm{Fe}(\mathrm{OH})_{3}, \mathrm{Fe}(\mathrm{OOH}), \mathrm{Fe}_{2} \mathrm{O}_{3}, \mathrm{Fe}(\mathrm{OH})_{2}, \mathrm{FeCO}_{3}, \mathrm{Al}(\mathrm{OH})_{3}\right)$. The largest hydraulic conductivity reduction was $34 \%$ near the inlet to the column, with a $27 \%$ reduction mid-way along the column and $4 \%$ near the end of the column. The predicted and experimental values of hydraulic conductivity were in good agreement, which implies that the predicted values of porosity reflect a similar trend from the Kozeny Carmen relationship. The column experiments showed that recycled concrete was able to maintain an almost neutral pH for long period (160 PV of flow through the column) and removed $100 \%$ of the $\mathrm{Al}$ and $\mathrm{Fe}$ during this period. The concentrations of $\mathrm{Al}$ in the effluent began to increase after $210 \mathrm{PV}$ and that of Fe after $275 \mathrm{PV}$ of flow through the column. 
It appears that recycled concrete could be a suitable material for use in permeable reactive barriers intended to treat acidic water in typical acid sulphate soil terrains. The performance monitoring of the PRB for 6 years, which verifies its effectiveness, were reported. The average $\mathrm{pH}$ was around 7 within the PRB. The $\mathrm{pH}$ of the PRB has been decreasing slowly, compared to that in the column test. This is attributed to exhaustion of the alkalinity generating materials as well as fouling by precipitates over the surface of the materials.

\section{Acknowledgments}

The authors acknowledge funding from the Australian Research Council (ARC) and industry partners Southern Rivers Catchment Management Authority (SRCMA), Douglas Partners Pty Ltd. and Manildra Group, with special thanks to Glenys Lugg. Support of Dr. Long Nghiem is greatly appreciated. The authors acknowledge Bob Rowlan (University of Wollongong) for his technical assistance during this study and Gyanendra Regmi for his contribution to this research. The second author's $\mathrm{PhD}$ scholarship was sponsored through the Endeavour Scholarship Scheme by the Australian Commonwealth Government.

\section{References}

[1] Dent D. Reclamation of acid sulphate soils. Advances in Soil Science 1992;17:79122.

[2] Indraratna B, Sullivan J, Nethery A. Effect of groundwater table on formation of acid sulphate soils. Minewater and the Environment 1995;14:71-84.

[3] Regmi G, Indraratna B, Nghiem LD. Effective remediation of groundwater in acid sulphate soil terrain. Australian Geomechanics 2009;44:33-40.

[4] Blowes DW, Ptacek CJ, Benner SG, McRae CWT, Bennett TA, Puls RW. Treatment of inorganic contaminants using permeable reactive barriers. Journal of Contaminant Hydrology 2000;45(1-2):123-137.

[5] Li L, Benson CH, Lawson EM. Modeling porosity reductions caused by mineral fouling in continuous-wall permeable reactive barriers. Journal of Contaminants Hydrology 2006;83:89-121. 
[6] Kalinovich I, Rutter A, Poland JS,Cairns G and Rowe RK. Remediation of PCB contaminated soils in the canadian arctic: Excavation and Surface PRB Technology. Science of Total Environment 2008;407:53-66.

[7] Kalinovich I, Rutter A, Rowe RK, Poland JS. Design and application of surface PRBs for PCB remediation in the Canadian Arctic. Journal of Environmental Management 2012);101:124-133.

[8] Golab AN, Peterson MA, Indraratna B. Selection of potential reactive materials for a permeable reactive barrier for remediating acidic groundwater in acid sulphate soil terrains. Quarterly Journal of Engineering Geology and Hydrogeology 2006;39:209223.

[9] Waite DT, Desmier R, Melville M, Macdonald B, Lavitt N. Preliminary investigation into the suitability of permeable reactive barriers for the treatment of acid sulfate soils discharge. Handbook of Groundwater Remediation Using Permeable Reactive Barriers: Applications to Radionuclides, Trace Metals, and Nutrients. D. L. Naftz, S. J. Morrison, C. C. Fuller and J. A. Davis. San Francisco, Academic Press; 2002, p. 67-104.

[10] McMahon PB, Dennehy KF, Sandstrom MW. Hydraulic and geochemical performance of a permeable reactive barrier containing zero-valent iron, Denver Federal Center. Ground Water 1999;37(3):396-404.

[11] Puls RW, Blowes DW, Gillham RW. Long-term performance monitoring for a permeable reactive barrier at the U.S. Coast Guard Support Center, Elizabeth City, North Carolina. Journal of Hazardous Materials 1999;68(1-2):109-124.

[12] Vidic RD. Permeable reactive barriers: Case study review. GWRTAC E-Series Technology Evaluation Rep. TE-01-01. Pittsburgh, Ground-Water Remediation Technologies Analysis Center; 2001, p. 49.

[13] Naftz DL, Fuller CC, Davis JA, Morrison SJ, Feltcorn EM, Freethey GW, Rowland RC, Wilkowske C, Piana M. Field demonstration of three permeable reactive barriers to control uranium contamination in groundwater, Fry Canyon, Utah. Handbook of Groundwater Remediation Using Permeable Reactive Barriers: Applications to Radionuclides, Trace Metals, and Nutrients. San Francisco, Academic Press; 2002, p. 401-434. 
[14] Wilkin RT, Puls RW, Sewell GW. Long-term performance of permeable reactive barriers using zero-valent iron: geochemical and microbiological effects. Ground Water 2003;41(4):493-503.

[15] Sarr D. Zero-valent-iron permeable reactive barriers - How long will they last? Remediation 2001;11(2):1-18.

[16] Indraratna B, Regmi G, Nghiem LD. Performance of a PRB for the remediation of acidic groundwater in acid sulphate soil terrain. Journal of Geotechnical and Geoenvironmental Engineering, ASCE 2010;136.

[17] Mackenzie PD, Horney DP, Sivavec TM. Mineral precipitation and porosity losses in granular iron columns. Journal of Hazardous Materials 1999;68(1-2):1-17.

[18] Phillips DH, Gu B, Watson DB, Roh Y,Liang L, Lee SY. Performance evaluation of a zerovalent iron reactive barrier: Mineralogical characteristics. Environmental Science \& Technology 2000;34(19):4169-4176.

[19] Rowe R,Armstrong M, Cullimore D. Particle Size and Clogging of Granular Media Permeated with Leachate. Journal of Geotechnical and Geoenvironmental Engineering, ASCE 2000;126(9):775-786.

[20] Rowe RK. Long-term performance of contaminant barrier systems. Geotechnique 2005;55(9):631-678.

[21] Jeen S-W, Mayer KU, Gillham RW, Blowes DW. Reactive Transport Modeling of Trichloroethene Treatment with Declining Reactivity of Iron. Environemntal Science and Technology 2007;41:1432-1438.

[22] Regmi G, Indraratna B, Nghiem L. Long-term Performance of a Permeable Reactive Barrier in Acid Sulphate Soil Terrain. Water, Air \& Soil Pollution: Focus 2009;9(5):409-419.

[23] Jeen S-W, Amos RT and Blowes DW. Modeling Gas Formation and Mineral Precipitation in a Granular Iron Column. Environemental Science and Technology 2012;46:6742-6749.

[24] Pathirage PU, Indraratna B, Nghiem LD, Banasiak L, Regmi G. Armouring by precipitates and the associated reduction in hydraulic conductivity of recycled concrete aggregates used in a novel PRB for the treatment of acidic groundwater. 11th Australia - New Zealand Conference on Geomechanics: Ground Engineering in a Changing World. Melbourne, Australia 2012;828-833. 
[25] Mayer KU, Blowes DW, Frind EO. Reactive transport modeling of an in situ reactive barrier for the treatment of hexavalent chromium and trichloroethylene in groundwater. Water Resources Research 2001;37(12): 3091-3103.

[26] Li L, Benson CH. Impact of fouling on the long-term hydraulic behaviour of permeable reactive barriers. IAHS-AISH Publication; 2005,(298):p. 23-31.

[27] Regmi G, Indraratna B, Nghiem LD, Golab AN. Treatment of Acidic Groundwater in Acid Sulphate Soil Terrain Using Recyced Concrete: Column Experiments. Journal of Environmental Engineering, ASCE 2011;137(6):433-443.

[28] Liang L, Sullivan AB, West OR, Moline GR, Kamolpornwijit W. Predicting the precipitation of mineral phases in permeable reactive barriers. Environmental Engineering Science 2003;20(6): 635-653.

[29] Johnson RL, Tratnyek PG,Miehr R,Thoms RB, Banstra JZ. Reduction of Hydraulic Conductivity and Reactivity in Zero-Valent Iron Columns by Oxygen and TNT. Groundwater Monitoring and Remediation 2005;25(1):129-136.

[30] APHA. Standard Methods for the Examination of Water and Wastewater. Washington, 20th Edition, American Public Health Association 1998.

[31] Yabusaki S. Multicomponent reactive transport in an in situ zero-valent iron cell. Environmental Science and Technology 2001;35(7):1493-1503.

[32] Mayer KU, Benner SG, Blowes DW. Process-based reactive transport modeling of a permeable reactive barrier for the treatment of mine drainage. Journal of Contaminant Hydrology 2006;85(3-4):195-211.

[33] Steefel CI, Lasaga AC. A coupled model for transport of multiple chemical-species and kinetic precipitation dissolution reactions with application to reactive flow in single-phase hydrothermal systems. American Journal of Science 1994;294(5):529592.

[34] Amos RT, Mayer KU, Blowes DW, Ptacek CJ. Reactive transport modeling of column experiments for the remediation of acid mine drainage. Environmental Science and Technology 2004;38(11):3131-3138.

[35] Krauskopf KB, Bird DK. Introduction to Geochemistry. McGraw-Hill, New York; 1995.

[36] Walter AL, Frind EO, Blowes DW, Ptacek CJ, Molson JW. Modeling of multicomponent reactive transport in groundwater, Model development and evaluation. Water Resour. Res. 1994;30(11):3137-3148. 
[37] Harbaugh AW. MODFLOW-2005, The U.S. Geological Survey modular groundwater model - the Ground-Water Flow Process: U.S. Geological Survey Techniques and Methods 6-A16, 2005.

[38] Indraratna, B., L.S.S. Wijewardana, and A.S. Balasubramaniam (1993), Large-scale triaxial testing of greywacke rockfill, Geotechnique, 43 (1), 37-51.

[39] Indratana, B., D. Ionescu, and H.D. Christie (1998), Shear behaviour of railway ballast on large-scale triaxial tests, Journal of Geotechnical and Geoenvironmetal Engineering, 439-449.

[40] Clement TP. RT3D: A Modeular Computer Code for Simulating Reactive MultiSpecies Transport in 3-Dimensional Groundwater Aquifers, PNNL-SA-11720 P. N. N. Laboratory. Richland, Washington 1997.

[41] Rowe RK, Quigley RM, Brachman RWI, Booker JR. Barrier Systems for Waste Disposal. London, Spon Press; 2004.

[42] Ouangrawa M, Molson J, Aubertin M, Bussiere B, Zagury GJ. Reactive transport modelling of mine tailings columns with capillarity induced high water saturation for preventing sulfide oxidation. Applied Geochemistry 2009;24(7):1312-1323.

[43] Jurjovec J, Blowes DW, Ptacek CJ, Mayer KU. Multicomponent reactive transport modeling of acid neutralization reactions in mine tailings. Water Resources Research 2004;40(11):W1120201-W1120217.

[44] Trani LDO, Indraratna B. Use of impedance probe for estimation of porosity changes in saturated granular filters under cyclic loading: Calibration and Application. Journal of Geotechnical and Geo-environemntal Engeineerns, ASCE 2010;1469-1474.

[45] Kamolpornwijit W, Liang L, Moline L, Hart T, West OR. Identification and quantification of mineral precipitation in $\mathrm{Fe}^{0}$ filings from a column study. Environmental Science \& Technology 2004;38(21):5757-5765.

[46] Bilek F. Column tests to enhance sulphide precipitation with liquid organic electron donators to remediate AMD-influenced groundwater. Environmental Geology 2006;49:674-683.

\section{Appendix A}

\section{Geochemical algorithm}


Bicarbonate buffering (maintenance of an almost neutral $\mathrm{pH}$ ) and complete removal of $\mathrm{Al}$ and Fe from the solution

$$
\begin{aligned}
& \mathrm{Ca}(\mathrm{OH})_{2}+2 \mathrm{H}^{+} \rightarrow \mathrm{Ca}^{2+}+2 \mathrm{H}_{2} \mathrm{O} \\
& \mathrm{Ca}(\mathrm{OH})_{2}+\mathrm{CO}_{2}(\mathrm{aq}) \rightarrow \mathrm{CaCO}_{3}+\mathrm{H}_{2} \mathrm{O} \\
& \mathrm{CaAl}_{2} \mathrm{Si}_{2} \mathrm{O}_{8}+8 \mathrm{H}^{+} \rightarrow \mathrm{Ca}^{2+}+2 \mathrm{Al}^{3+}+2 \mathrm{H}_{4} \mathrm{SiO}_{4} \\
& \mathrm{CaCO}_{3}+2 \mathrm{H}^{+} \Leftrightarrow \mathrm{Ca}^{2+}+\mathrm{H}_{2} \mathrm{CO}_{3} \\
& \mathrm{CaCO}_{3}+\mathrm{H}_{2} \mathrm{CO}_{3} \Leftrightarrow \mathrm{Ca}^{2+}+2 \mathrm{HCO}_{3}^{-} \\
& \mathrm{CO}_{2}(\mathrm{aq})+\mathrm{H}_{2} \mathrm{O} \Leftrightarrow \mathrm{H}_{2} \mathrm{CO}_{3}
\end{aligned}
$$

Dissolution/Precipitation

Dissolution of $\mathrm{Ca}$ bearing minerals and precipitation secondary minerals were assumed to follow the transition state theory with following expressions;

$$
\begin{aligned}
& r=-k_{e f f}\left(1-\frac{I A P}{K_{e q}}\right) \\
& \frac{d\left[m_{\mathrm{Ca}(\mathrm{OH})_{2}}\right]}{d t}=\frac{1}{2} \frac{d\left[\mathrm{H}^{+}\right]}{d t}=-\frac{d\left[\mathrm{Ca}^{2+}\right]}{d t}=r_{1\left[\mathrm{Ca}^{2+}\right]}=k_{\left[\mathrm{Ca}^{2+}\right]}\left[\frac{a_{\mathrm{Ca}^{2+} a_{\mathrm{OH}^{-}}^{2}}}{K_{e q, \mathrm{Ca}^{2+}, \mathrm{OH}^{-}}}-1\right] \\
& \frac{d\left[m_{\mathrm{CaAl}_{2} \mathrm{Si}_{2} \mathrm{O}_{8}}\right]}{d t}=\frac{1}{8} \frac{d\left[\mathrm{H}^{+}\right]}{d t}=-\frac{d\left[\mathrm{Ca}^{2+}\right]}{d t}=-\frac{1}{2} \frac{d\left[\mathrm{Al} l^{3+}\right]}{d t}=\eta_{\left[\mathrm{Ca}^{2+} \mathrm{Al} l^{3+}\right]}=k_{\left[\mathrm{Ca}^{2+} \mathrm{Al} l^{3+}\right]}\left[\frac{a_{\mathrm{Ca}^{2+} a_{\mathrm{Al}^{3+}}^{2}}}{K_{e q, \mathrm{Ca}^{2+} \mathrm{Al} l^{3+}}}-1\right] \\
& \frac{d\left[m_{\mathrm{CaCO}_{3}}\right]}{d t}=\frac{1}{2} \frac{d\left[\mathrm{H}^{+}\right]}{d t}=-\frac{d\left[\mathrm{Ca}^{2+}\right]}{d t}=-\frac{d\left[\mathrm{H}_{2} \mathrm{CO}_{3}\right]}{d t}=r_{2\left[\mathrm{Ca}^{2+}\right]}=k_{\left[\mathrm{Ca}^{2+}\right]}\left[\frac{a_{\mathrm{Ca}^{2+} a_{\mathrm{CO}_{3}^{2-}}}}{\mathrm{K}_{e q, \mathrm{Ca}^{2+}, \mathrm{CO}_{3}^{2-}}}-1\right] \\
& \frac{d\left[m_{\left.\mathrm{CaCO}_{3}\right]}\right]}{d t}=\frac{d\left[\mathrm{H}_{2} \mathrm{CO}_{3}\right]}{d t}=-\frac{d\left[\mathrm{Ca}^{2+}\right]}{d t}=-\frac{1}{2} \frac{d\left[\mathrm{HCO}_{3}^{-}\right]}{d t}=r_{3\left[\mathrm{Ca}^{2+}\right]}=k_{\left[\mathrm{Ca}^{2+}\right]}\left[\frac{a_{\mathrm{Ca}^{2+} a_{\mathrm{HCO}_{3}^{-}}}}{K_{e q, \mathrm{Ca}^{2+}, \mathrm{HCO}_{3}^{-}}}-1\right] \\
& \mathrm{Fe}^{3+}+3 \mathrm{H}_{2} \mathrm{O} \rightarrow \mathrm{Fe}(\mathrm{OH})_{3(S)}+3 \mathrm{H}_{a q}^{+}
\end{aligned}
$$

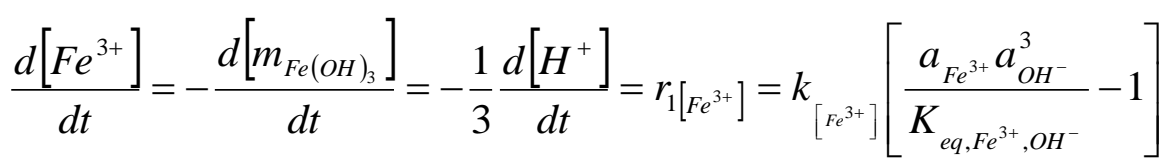




$$
\begin{aligned}
& \mathrm{Fe}^{3+}+2 \mathrm{H}_{2} \mathrm{O} \rightarrow \mathrm{Fe}(\mathrm{OOH})+3 \mathrm{H}_{a q}^{+} \\
& \frac{d\left[\mathrm{Fe}^{3+}\right]}{d t}=-\frac{d\left[m_{\mathrm{Fe}(\mathrm{OOH})}\right]}{d t}=-\frac{1}{3} \frac{d\left[\mathrm{H}^{+}\right]}{d t}=r_{2\left[\mathrm{Fe}^{3+}\right]}=k_{\left[\mathrm{Fe}^{3+}\right]}\left[\frac{a_{\mathrm{Fe}^{3+}} a_{\mathrm{OOH}^{3-}}}{K_{e q, \mathrm{Fe}^{3+}, \mathrm{OOH}^{3-}}}-1\right] \\
& 2 \mathrm{Fe}^{3+}+3 \mathrm{H}_{2} \mathrm{O} \rightarrow \mathrm{Fe}_{2} \mathrm{O}_{3}+6 \mathrm{H}_{a q}^{+} \\
& \frac{1}{2} \frac{d\left[\mathrm{Fe}^{3+}\right]}{d t}=-\frac{d\left[m_{\mathrm{Fe}_{2} \mathrm{O}_{3}}\right]}{d t}=-\frac{1}{6} \frac{d\left[H^{+}\right]}{d t}=r_{3\left[\mathrm{Fe}^{3+}\right]}=k_{\left[\mathrm{re}^{3+]}\right]}\left[\frac{a_{\mathrm{Fe}^{3+}}^{2} a_{\mathrm{O}^{2-}}^{3}}{K_{e q, F e^{3+}, O^{2-}}}-1\right] \\
& \mathrm{Al}^{3+}+3 \mathrm{H}_{2} \mathrm{O} \rightarrow \mathrm{Al}(\mathrm{OH})_{3(S)}+3 \mathrm{H}^{+}{ }_{(a q)} \\
& \frac{d\left[A l^{3+}\right]}{d t}=-\frac{d\left[m_{A l(O H)_{3}}\right]}{d t}=-\frac{1}{3} \frac{d\left[H^{+}\right]}{d t}=\eta_{\left[l^{3+}\right.}=k_{\left[A l^{3+}\right.}\left[\frac{a_{A l^{3+}} a_{O H^{-}}^{3}}{K_{e q, A l^{3+}, O H^{-}}}-1\right] \\
& \mathrm{Fe}^{2+}+2(\mathrm{OH})^{-} \leftrightarrow \mathrm{Fe}(\mathrm{OH})_{2(\mathrm{~S})} \\
& \frac{d\left[\mathrm{Fe}^{2+}\right]}{d t}=\frac{1}{2} \frac{d\left[\mathrm{OH}^{-}\right]}{d t}=-\frac{d\left[m_{\mathrm{Fe}(\mathrm{OH})_{2}}\right]}{d t}=r_{1\left[\mathrm{Fe}^{2+}\right]}=k_{\left[\mathrm{Fe}^{2+}\right]}\left[\frac{a_{\mathrm{Fe}^{2+}} a_{\mathrm{OH}^{-}}^{2}}{K_{e q, \mathrm{Fe}^{2+}, \mathrm{OH}^{-}}}-1\right] \\
& \mathrm{Fe}^{2+}+\mathrm{CO}_{3}^{2-} \leftrightarrow \mathrm{FeCO}_{3(S)} \\
& \frac{d\left[\mathrm{Fe}^{2+}\right]}{d t}=\frac{d\left[\mathrm{CO}_{3}^{2-}\right]}{d t}=-\frac{d\left[m_{\mathrm{FeCO}}\right]}{d t}=r_{2\left[\mathrm{Fe}^{2+}\right]}=k_{\left[\mathrm{Fe}^{2+}\right]}\left[\frac{a_{\mathrm{Fe}^{2+}} a_{\mathrm{CO}_{3}^{2-}}}{K_{e q, \mathrm{Fe}^{2+}, \mathrm{CO}_{3}^{2-}}}-1\right] \\
& \mathrm{Ca}^{2+}+\mathrm{CO}_{3}^{2-} \leftrightarrow \mathrm{CaCO}_{3(S)} \\
& \frac{d\left[\mathrm{Ca}^{2+}\right]}{d t}=\frac{d\left[\mathrm{CO}_{3}^{2-}\right]}{d t}=-\frac{d\left[m_{\mathrm{CaCO}_{3}}\right]}{d t}=r_{4}\left[\mathrm{Ca}^{2+}\right]=k_{\left[\mathrm{Ca}^{2+}\right]}\left[\frac{a_{\mathrm{Ca}^{2+} a_{\mathrm{CO}_{3}^{2-}}}}{K_{e q, \mathrm{Ca}^{2+}, \mathrm{CO}_{3}^{2-}}}-1\right]
\end{aligned}
$$

The overall reactive kinetics for each species in the algorithm are listed as:

$$
\begin{aligned}
& \frac{d\left[\mathrm{Ca}^{2+}\right]}{d t}=-r_{1}\left[\mathrm{Ca}^{2^{+}}\right]-\eta_{\left[a^{2+} \mathrm{Al}^{3+}\right]}-r_{2\left[\mathrm{Ca}^{2+}\right]}-r_{3}\left[\mathrm{Ca}^{2+}\right]+r_{4}\left[\mathrm{Ca}^{2+}\right] \\
& \frac{d\left[\mathrm{Fe}^{3+}\right]}{d t}=r_{1}\left[\mathrm{Fe}^{3+}\right]+r_{2}\left[\mathrm{Fe}^{3+}\right]+2 r_{3\left[\mathrm{Fe}^{3+}\right]} \\
& \frac{d\left[\mathrm{Fe}^{2+}\right]}{d t}=r_{1}\left[\mathrm{Fe}^{2+}\right]+r_{2}\left[\mathrm{Fe}^{2+}\right] \\
& \frac{d\left[A l^{3+}\right]}{d t}=\eta_{A l^{3+}}-2 \eta_{\left.\mathrm{Ca}^{2+} \mathrm{Al} l^{3^{+}}\right]} \\
& \frac{d\left[\mathrm{H}^{+}\right]}{d t}=2 r_{1\left[\mathrm{Ca}^{2+}\right]}+8 r_{\left[\mathrm{Ca}^{2+} \mathrm{Al} \mathrm{l}^{3+}\right]}+2 r_{2\left[\mathrm{Ca}^{2+}\right]}-3 r_{1\left[\mathrm{Fe}^{3+}\right]}-3 r_{2\left[\mathrm{Fe}^{3+}\right]}-6 r_{3\left[\mathrm{Fe}^{3+}\right]}-3 \eta_{\left.\mathrm{Al}^{3+}\right]} \\
& \frac{d\left[\mathrm{HCO}_{3}^{-}\right]}{d t}=-r_{2\left[\mathrm{Ca}^{2+}\right]}-2 r_{3\left[\mathrm{Ca}^{2+}\right]}+r_{2\left[\mathrm{Fe}^{2+}\right]}+r_{4}\left[\mathrm{Ca}^{2+}\right]
\end{aligned}
$$


All the $\mathrm{m}_{\mathrm{i}}$ is considered for a volume of $10^{-3} \mathrm{~m}^{3}$ which is equivalent to $1 \mathrm{~L}$ ( $\mathrm{i}=$ all the solid phase minerals).

\section{Appendix B}

The groundwater flow at transient condition is considered, and the governing equation for one dimension flow is given by;

$\frac{\partial^{2} h}{\partial x^{2}}=\nabla^{2} h=\frac{S}{T}\left(\frac{\partial h}{\partial t}\right)$

$T=K b$

The solution for Eq. (B.1) can be written as,

Let $\mathrm{b} / S=A$, as $S$ and $b$ are assumed to be constants throughout the simulation, hence,

$\nabla^{2} h=\frac{1}{A K}\left(\frac{\partial h}{\partial t}\right)$

Now, we assume a solution of separating variable type for Eq. (B.1) as follows;

$h(x, t)=X(x) T(t)$ and $K\left(t_{1}\right)=T_{1}\left(t_{1}\right)$

Substitution of $h=X . T$ and $K=T_{1}$ into Eq. (B.3) yields;

$X^{\prime \prime} \cdot T=\frac{X}{A} \cdot \frac{T^{\prime}}{T_{1}}$

where the prime denotes differentiation with respect to the appropriate variable.

Dividing by X.T, we obtain,

$\frac{X^{\prime \prime}}{X}=\frac{1}{A} \cdot \frac{T^{\prime}}{T} \cdot \frac{1}{T_{1}}=-\mu^{2}$

where $\mu$ is an arbitrary constant, thus,

$\frac{X^{\prime \prime}}{X}=-\mu^{2}$

and 
$\frac{1}{A} \cdot \frac{T^{\prime}}{T} \cdot \frac{1}{T_{1}}=-\mu^{2}$

$\frac{T^{\prime}}{T}=-\mu^{2} A T_{1}$

$\int \frac{T^{\prime}}{T} d t=-\mu^{2} A \int_{1} d t$

$$
\ln (T)=-\mu^{2} A \int \frac{K_{0}\left(\frac{n_{0}+\sum_{k=1}^{N_{m}} M_{k} R_{k} t}{n_{0}}\right)^{3}}{\left(\frac{1-\left(n_{0}+\sum_{k=1}^{N_{m}} M_{k} R_{k} t\right)}{1-n_{0}}\right)^{2}} d t
$$

Let $\alpha=n_{0}+\sum_{k=1}^{N_{m}} M_{k} R_{k} t$ and $\beta=1-n_{0}-\sum_{k=1}^{N_{m}} M_{k} R_{k} t$

$$
\begin{aligned}
& \frac{\partial \alpha}{\partial t}=\sum_{k=1}^{N_{m}} M_{k} R_{k} \\
& \ln (T)=-\frac{\mu^{2} A K_{0}}{\sum_{k=1}^{N_{m}} M_{k} R_{k}} \frac{\left(1-n_{0}\right)^{2}}{n_{0}^{3}} \int \frac{\alpha^{3}}{(1-\alpha)^{2}} d \alpha \\
& \ln (T)=-\frac{\mu^{2} b K_{0}}{S \sum_{k=1}^{N_{m}} M_{k} R_{k}} \frac{\left(1-n_{0}\right)^{2}}{n_{0}^{3}}\left[\alpha^{2}(1.5+1 / \beta)-3(\alpha+\ln \beta)\right] \\
& T=\exp \left[-\frac{\mu^{2} b K_{0}}{S \sum_{k=1}^{N_{m}} M_{k} R_{k}} \frac{\left(1-n_{0}\right)^{2}}{n_{0}^{3}}\left\{\alpha^{2}(1.5+1 / \beta)-3(\alpha+\ln \beta)\right\}\right]
\end{aligned}
$$

From Eq. (B.4);

$$
X=C \sin \mu x+D \cos \mu x
$$


where, $C$ and $D$ are integral constants.

Therefore, the general solution for Eq. (B.3) can be written as,

$h=\left(\exp \left[-\frac{\mu^{2} b K_{0}}{S \sum_{k=1}^{N_{m}} M_{k} R_{k}} \frac{\left(1-n_{0}\right)^{2}}{n_{0}^{3}}\left\{\alpha^{2}(1.5+1 / \beta)-3(\alpha+\ln \beta)\right\}\right] \cdot(C \sin \mu x+D \cos \mu x)\right.$

\section{Notations}

$\mathrm{r} \quad=$ Reaction rate $\left(\right.$ molm $\left.^{-3}{ }_{\text {bulk }} \mathrm{s}^{-1}\right)$

$k_{\text {eff }}=$ Effective rate coefficient $\left(\mathrm{molm}^{-3}{ }_{\text {bulk }} \mathrm{s}^{-1}\right)$

IAP = Ion activity product (depend on the reaction)

$K_{e q} \quad=$ Solubility constant (depend on the reaction)

$S_{F^{0}} \quad=$ Current reactive surface area of zero-valent iron $\left(\mathrm{m}^{2}\right)$

$S_{F e^{0}}^{0} \quad=$ Initial reactive surface area of zero-valent iron $\left(\mathrm{m}^{2}\right)$

$\varphi_{F^{0}} \quad=$ Current volume fraction of zero-valent iron

$\varphi_{F^{0} e^{0}}^{0} \quad=$ Initial volume fraction of zero-valent iron

SI = Saturation index

$\Phi_{k} \quad=$ Volume fraction of mineral

$M_{k} \quad=$ Mineral molar volume $\left(\mathrm{m}^{3} \mathrm{~mol}^{-1}\right)$

$R_{k}=$ Overall reaction rate for the mineral $\left(\mathrm{molm}^{-3}{ }_{\text {bulk }} \mathrm{s}^{-1}\right)$

$\mathrm{t} \quad=$ Time $(\mathrm{s})$

$n_{o} \quad=$ Initial porosity

$n_{t} \quad=$ Porosity at time $\mathrm{t}$

$N_{m} \quad=$ Number of minerals

$K_{0} \quad=$ Initial hydraulic conductivity $\left(\mathrm{ms}^{-1}\right)$

$K=$ Hydraulic conductivity at time $t\left(\mathrm{~ms}^{-1}\right)$

$S \quad=$ Storage co-efficient

$T \quad=$ Transmissivity $\left(\mathrm{m}^{2} \mathrm{~s}^{-1}\right)$

$h \quad=$ Head $(\mathrm{m})$

$\mathrm{b}=$ Aquifer thickness $(\mathrm{m})$

$\mu, C, D=$ Constants

$l \quad=$ Length of the column (m)

$C \quad=$ Aqueous species concentration $\left(\mathrm{mgL}^{-1}\right)$

$D \quad=$ Hydrodynamic dispersion coefficient (m)

$v \quad=$ Seepage velocity $\left(\mathrm{ms}^{-1}\right)$

$R \quad=$ Retardation coefficient

$\Lambda \quad=$ First-order decay constant

$\tilde{C} \quad=$ Solid species concentration $\left(\mathrm{mgm}^{-3}\right)$

$\tilde{r} \quad=$ Kinetic reaction expression for the solid phase $\left(\right.$ molm $\left.^{-3}{ }_{\text {bulk }} \mathrm{s}^{-1}\right)$ 